\title{
DUCTILE BEHAVIOUR OF REINFORCED MASONRY COLUMNS
}

\author{
H. Singh ${ }^{1}$ and N. Cooke ${ }^{2}$
}

\begin{abstract}
This paper presents the results of an experimental investigation into the strength and level of ductile performance of two reinforced concrete masonry columns and one reinforced clay brick column by Singh [1993]. The results show that strength of reinforced concrete and clay masonry can be predicted by using full cross-section dimensions. Columns constructed from concrete masonry behave in a ductile manner but clay masonry columns behave in a very limited ductile manner.
\end{abstract}

\section{INTRODUCTION}

This paper presents the results of an experimental investigation into the strength and level of ductile performance of two reinforced concrete masonry columns and one reinforced clay brick column by Singh [1993]. The authors found a dearth of published literature on the subject of masonry columns designed for ductile performance and tested to destruction. This paper looks at the behaviour of three column specimens designed and tested by the authors. Two were constructed from concrete masonry units 20.36 and 20.30 and one from $230 \times 90 \times 76 \mathrm{~mm}$ clay bricks. Typical cross sections are shown in Figure 1. The columns were subjected to cyclic lateral, horizontal loading and a constant vertical axial load.

The design of the two concrete masonry columns was based on the assumption that the concrete core of the column was the structural element and that the masonry face could be ignored in the analysis of strength and ductility. The core concrete and reinforcement both comply with NZS3101:1980 Code of Practice for the Design of Reinforced Concrete Members, in particular, the transverse reinforcement in the plastic hinge region closely follows the requirements for confinement.

The main objective of this experimental work was to determine whether the design approach for reinforced concrete columns using the current Standard could be applied to the design of reinforced masonry columns. The major departure from the reinforced concrete code approach lies in the determination of the strength and ductility of the clay masonry column. This was based on an ultimate compression strain 0.0025 , using the approach developed for masonry walls in the Code of Practice for the Design of Masonry Structures, NZS4230:1990.

I Formerly, post-graduate student, Department of Civil Engineering, University of Canterbury, Christchurch.

2 Senior Lecturer, Department of Civil Engineering, University of Canterbury, Christchurch (Member).

\section{DETAILS OF TEST SPECIMENS}

All the masonry columns were square in cross-section as in Figure 1. The concrete columns, Specimens 1 and 2, were each $390 \mathrm{~mm}$ square and the clay brick column, Specimen 3, was $330 \mathrm{~mm}$ square. The concrete columns were $1400 \mathrm{~mm}$ high and the clay brick column was $1200 \mathrm{~mm}$ high; height here is measured from the top of the top course to the bottom of the base course.

High strength steel was used as longitudinal reinforcement in preference to low strength steel for the concrete columns which were designed as confined columns. The reason for this choice was that the performance of the columns at high curvatures is improved by its use because the early strain hardening of the steel helps to compensate for the loss of moment capacity due to the reduction of contribution from the concrete. Grade 300 steel was used for the clay brick specimen because the clay masonry was expected to crush at small curvatures before yielding of the steel developed. The longitudinal steel was also selected to conform with the Code of Practice for the Design of Masonry Structures, NZS4230:1990.

The arrangements of the longitudinal and transverse hoop reinforcement used in each column are shown in Figures 2, 3 and 4 . The transverse reinforcement in the clay brick column was designed to conform with NZS3101 for shear only. The transverse hoop reinforcement in the concrete columns was designed for shear and additionally for confinement in the potential plastic hinge zone, as is the case for reinforced concrete columns.

The transverse hoop bars were anchored normally by a 135 degree bend around a longitudinal bar plus an extension beyond the bend of at least eight hoop bar diameters embedded in the concrete core. The spacing of the hoop sets in Specimen 1 was at $0.2 \mathrm{~h}$ as required by NZS3101. However, the spacing in Specimen 2 was $100 \mathrm{~mm}$, i.e. half the depth of one course $(0.25 \mathrm{~h})$, and was therefore greater than the Code limit. 

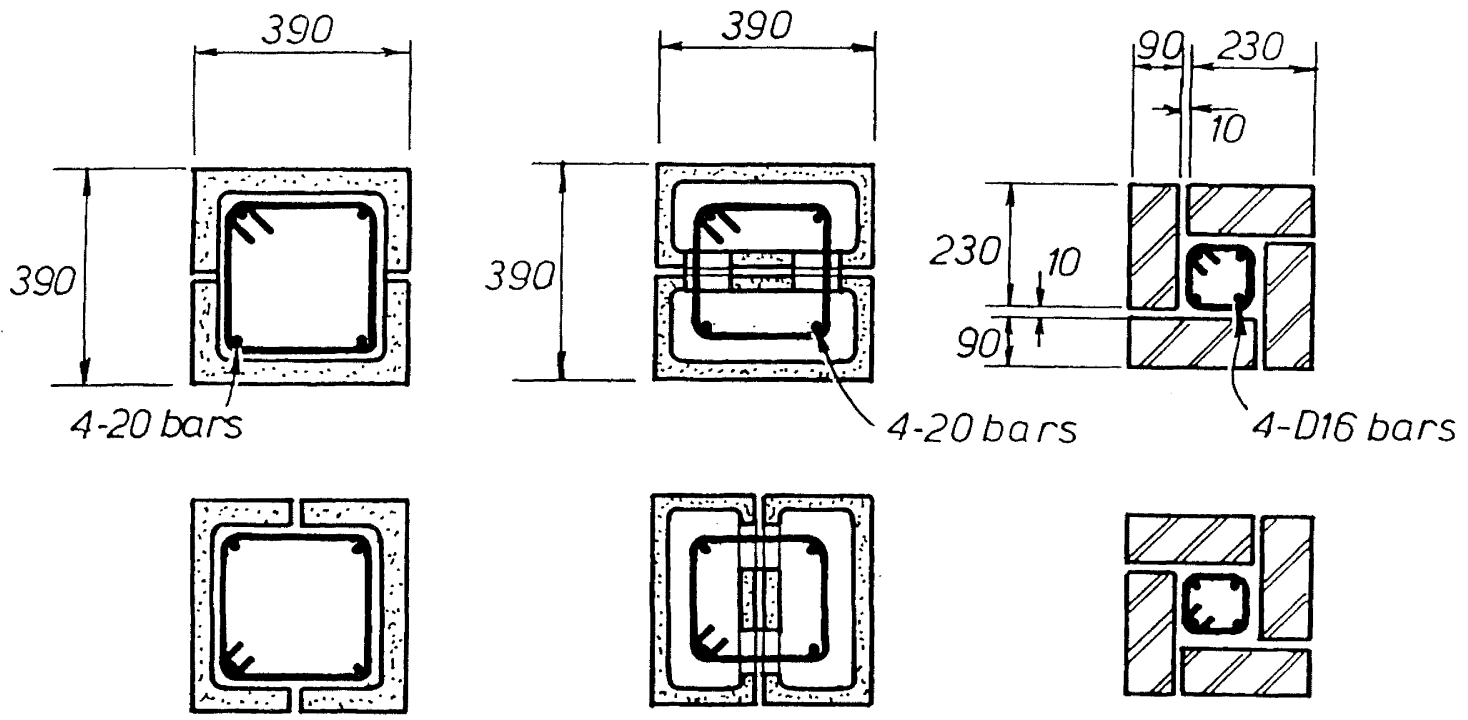

(b)

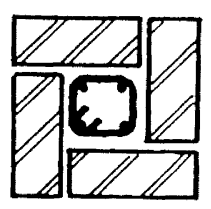

(c)

Figure 1. Crass-section details of (a) Specimen 1, concrete 20.36 units (b) Specimen 2 concrete 20.30 units and (c) Specimen 3, clay brick $230 \times 90 \times 76$ mm units.
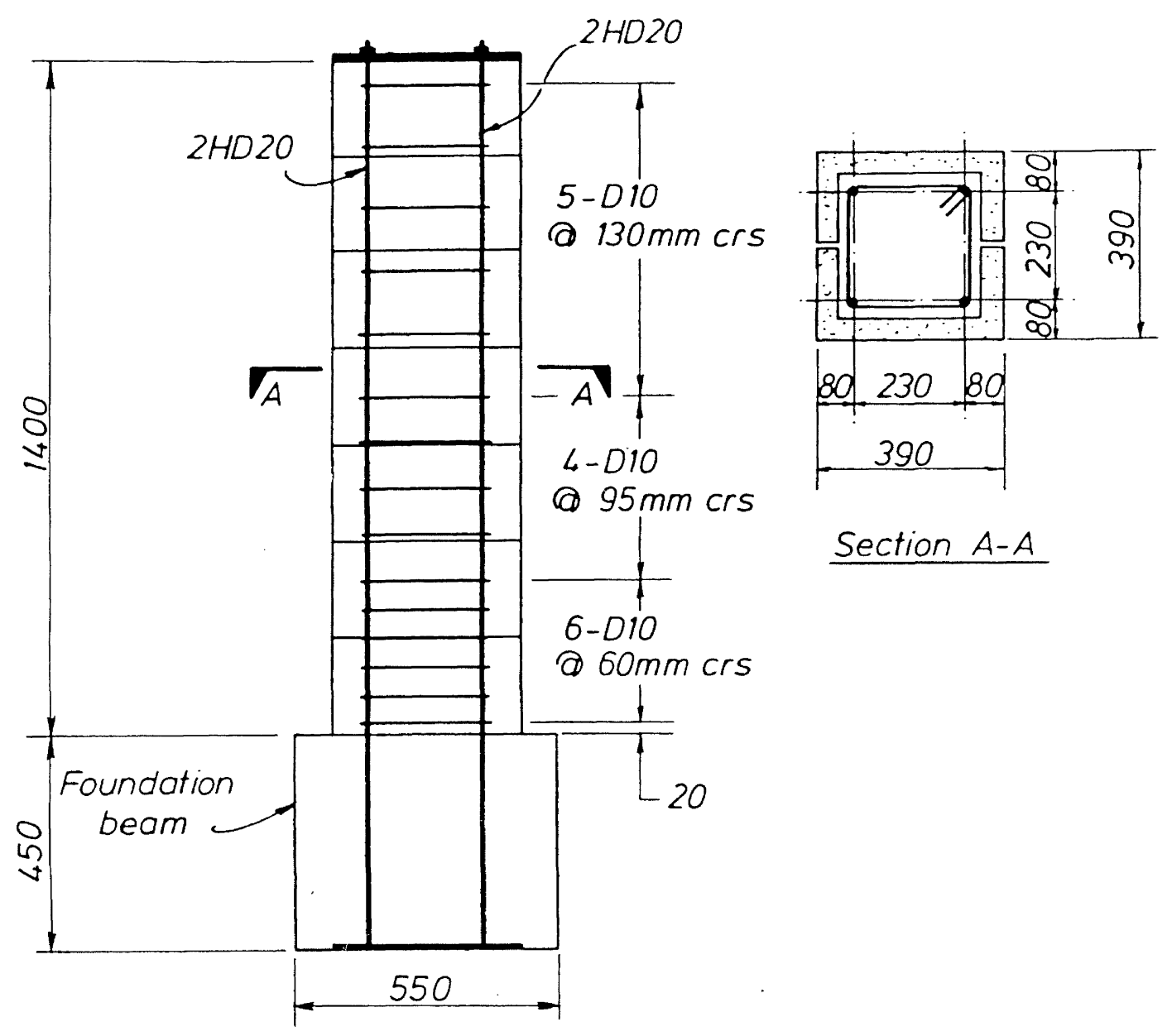

Section A-A

Figure 2 Specimen 1. Elevation and section. 


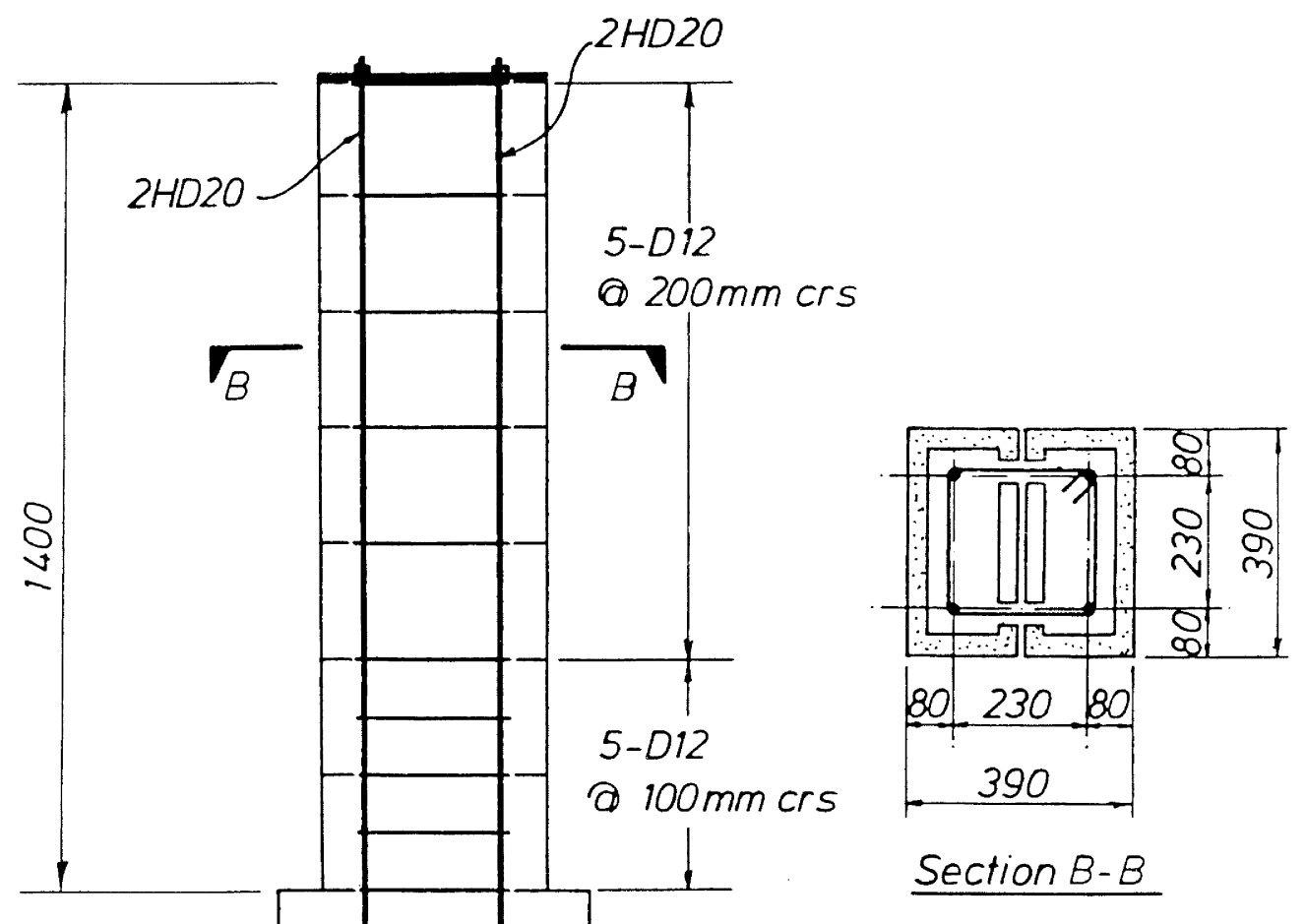

Figure 3. Specimen 2 Elevation and section

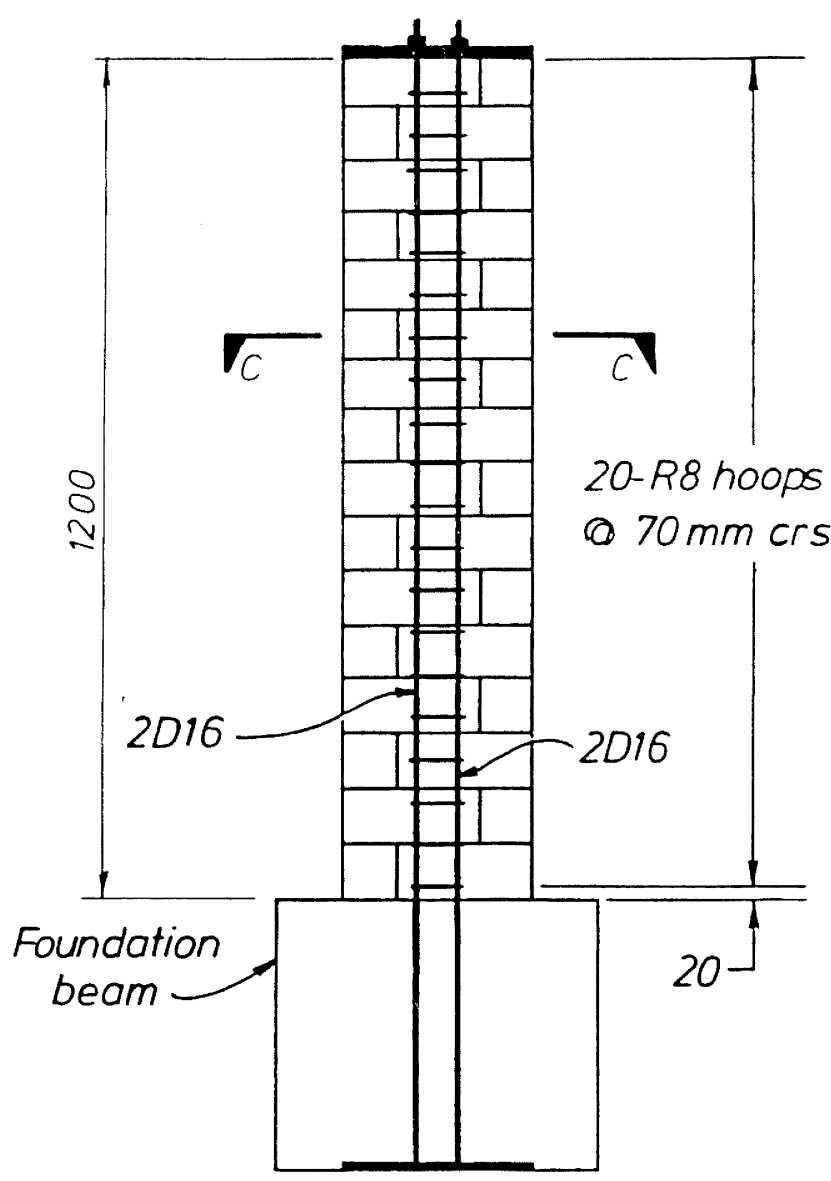

Figure 4. Specimen 3. Elevation and section.

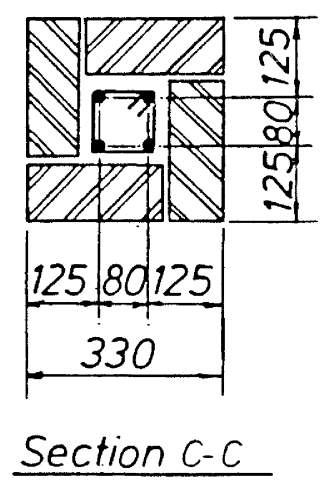


Table 1 Experimental material properties

\begin{tabular}{|l|c|c|}
\hline \multicolumn{1}{|c|}{ Material } & $\begin{array}{c}\text { Yield stress } \\
(\mathrm{MPa})\end{array}$ & $\begin{array}{c}\text { Strength } \\
(\mathrm{MPa})\end{array}$ \\
\hline $\begin{array}{l}\text { Grout for concrete masonry columns } \\
(28 \text { days }), \mathrm{f}_{\mathrm{g}}^{\prime}\end{array}$ & - & 16.6 \\
\hline $\begin{array}{l}\text { Grout for clay masonry columns } \\
(28 \text { days }), \mathrm{f}_{\mathrm{g}}^{\prime}\end{array}$ & - & 28.0 \\
\hline Mortar (28 days) & - & 12.3 \\
\hline Clay brick, $\mathrm{f}_{\mathrm{p}}^{\prime}$ & - & 36.6 \\
\hline 20.36 concrete masonry unit, $\mathrm{f}_{\mathrm{p}}^{\prime}$ & - & 27.8 \\
\hline 20.30 concrete masonry unit, $\mathrm{f}_{\mathrm{p}}^{\prime}$ & - & 34.6 \\
\hline Steel: D10 & 343 & 477 \\
\hline Steel: D12 & 328 & 454 \\
\hline Steel: D16 & 335 & 463 \\
\hline Steel: HD20 & 456 & 597 \\
\hline
\end{tabular}

The columns were laid up by a master mason. The construction of Specimen 1 was straightforward, except that, because the units were $\mathrm{C}$-shaped and were not tied together at each course, some movement of the upper units occurred when the concrete grout was poured. Transverse reinforcement can be provided at any spacing required by the design for both Specimens 1 and 3 . However, the reinforcement in Specimen 2 has to be provided at either each mortar joint only or at mid-height of the block as well as the mortar joint. This meant that Specimen 2 was much more difficult to construct because the central walls had to be cut in order to place the transverse reinforcement at the required centres in the potential plastic hinge zone. The clay brick column was also difficult to construct. It was built in three lifts because of the difficulty of pouring and compacting grout into the small central core.

Specimens 1 and 2 were grouted in one operation by the highlift grouting method. Specimen 3 was grouted in three operations by the low-lift grouting method; it was built up to a height of $425 \mathrm{~mm}$, grouted and then consolidated. The construction joint was then prepared, and the sequence was repeated for the next two operations. An expansive admixture was added to the grout for all three specimens.

The properties of the concrete and clay brick masonry units, concrete grout, mortar and steel reinforcement are shown in Table 1. The maximum aggregate size in the grout was $13 \mathrm{~mm}$. The slump was $190 \mathrm{~mm}$. The masonry strength, $\mathrm{f}_{m}^{\prime}$, was calculated from the following equations:

$$
f_{m}^{\prime}=0.59 x f_{c b}^{\prime}+0.90(1-x) f_{g}^{\prime} \ldots \ldots \ldots \ldots
$$

for ungrouted concrete masonry and

$$
f_{m}^{\prime}=x f_{p}^{\prime}+(1-x) f_{g}^{\prime}
$$

Table 2 Masonry Strengths for Specimens 1, 2 and 3

\begin{tabular}{||c|c|c|}
\hline \multirow{2}{*}{$\begin{array}{c}\text { Specimen } \\
\#\end{array}$} & \multicolumn{2}{|c|}{$\mathrm{f}_{\mathrm{m}}^{\prime}(\mathrm{MPa})$} \\
\cline { 2 - 3 } & $\begin{array}{c}\text { Theoretical } \\
\text { Eqs. 1 and } 2\end{array}$ & Prism Test \\
\hline 1 & 15.8 & 15.9 \\
\hline 2 & 17.8 & 20.6 \\
\hline 3 & 22.0 & \\
\hline
\end{tabular}

for grouted brick masonry. These equations are based on a rational analysis of the mechanics using Hilsdorf's failure criterion. They are confirmed by experimental data and may be found in the book by Paulay and Priestley [1991].

The masonry strengths using Eqs. 1 and 2 can be found in Table 2 with the results of grouted masonry prisms, three concrete blocks high.

\section{INSTRUMENTATION}

The axial compression load was applied to the column specimens by a prestressing system and the lateral load was applied by a hydraulic jack attached to a loading frame. The loading capacity of the jack was $330 \mathrm{kN}$ in tension and it could travel a maximum distance of $400 \mathrm{~mm}$. Figure 5 shows the test setup and loading arrangement. Figure 6 shows Specimen 2 near the end of the test at a displacement ductility factor of 10 . It also shows the vertical prestressing arrangement used to 


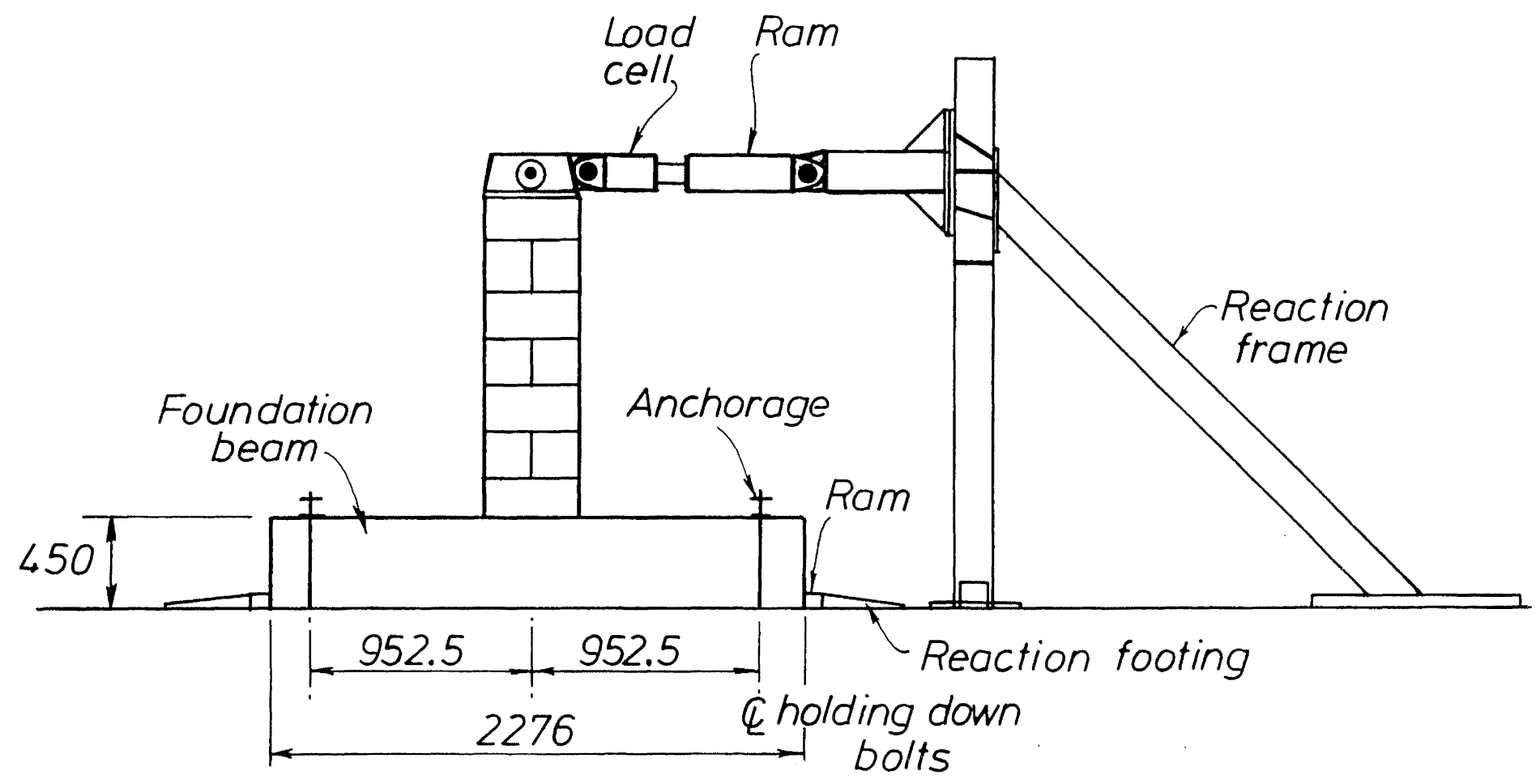

Figure 5. Test set-up and loading arrangement.

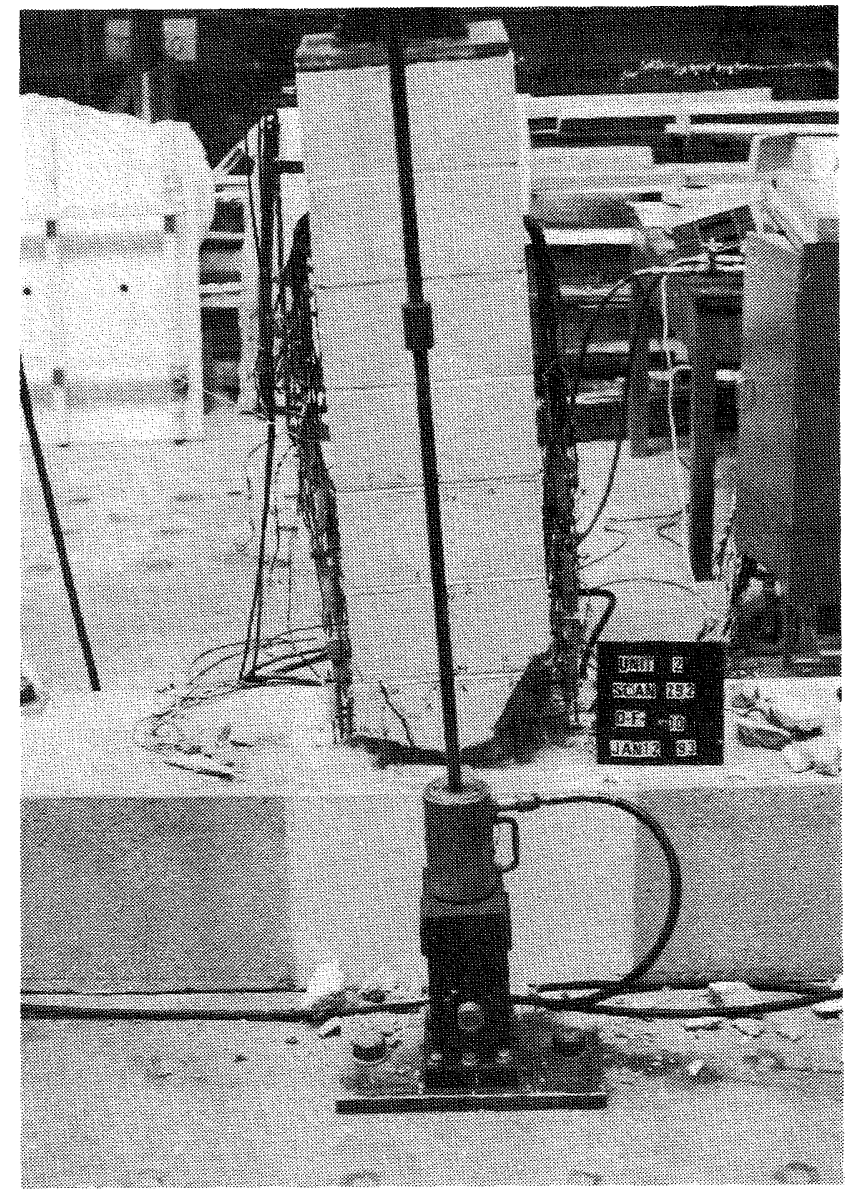

Figure 6. Specimen 2 at the end of the test. Vertical load is applied by prestressing tendons as shown.

represent the axial load. The prestressing consisted of two 25 mm diameter Macalloy high strength bars, stressed to $150 \mathrm{kN}$ each, connected to two 30 tonne jacks and pinned connections to the structural floor and the horizontal loading bracket on top of the columns. The axial load ratio of 0.10 (applied load/concrete strength) was chosen for these tests to represent the maximum likely masonry column axial load ratio to be found in practice.

Four pairs of linear potentiometers with $50 \mathrm{~mm}$ or $30 \mathrm{~mm}$ travel, aligned vertically at five levels above the base of the column, shown in Figure 6, were used to determine the average column curvatures and average longitudinal strains in the reinforcement and masonry. The potentiometers were supported on the steel brackets which in turn were attached to $12 \mathrm{~mm}$ diameter transverse steel rods passing through the column core concrete. Details of the arrangement of potentiometers and rods can be seen in Figure 7.

SHOWA N11-FA-5-120-11 electrical resistance strain gauges were attached to the longitudinal bars and hoops at various levels in order to measure the strains on the transverse and longitudinal reinforcement. 


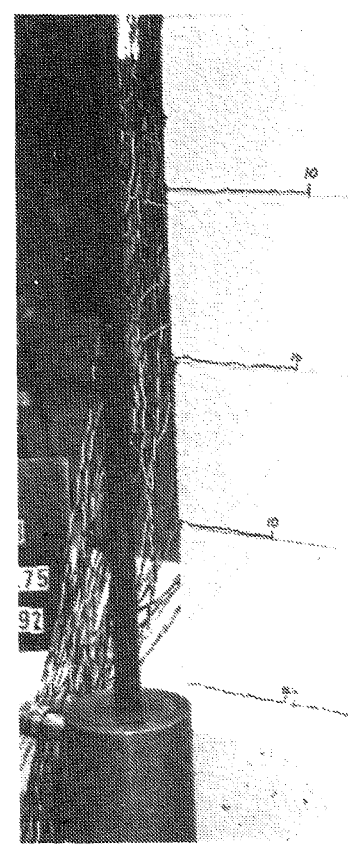

(a)

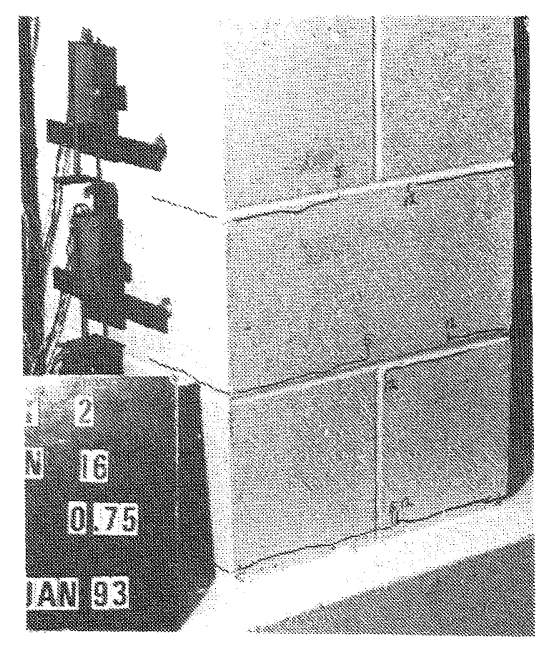

(d)

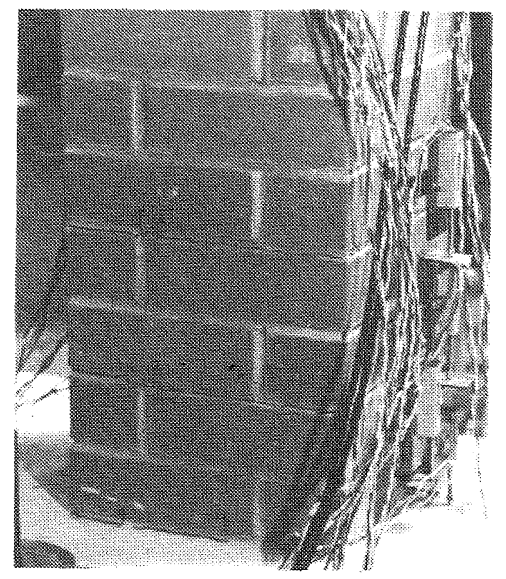

(g)

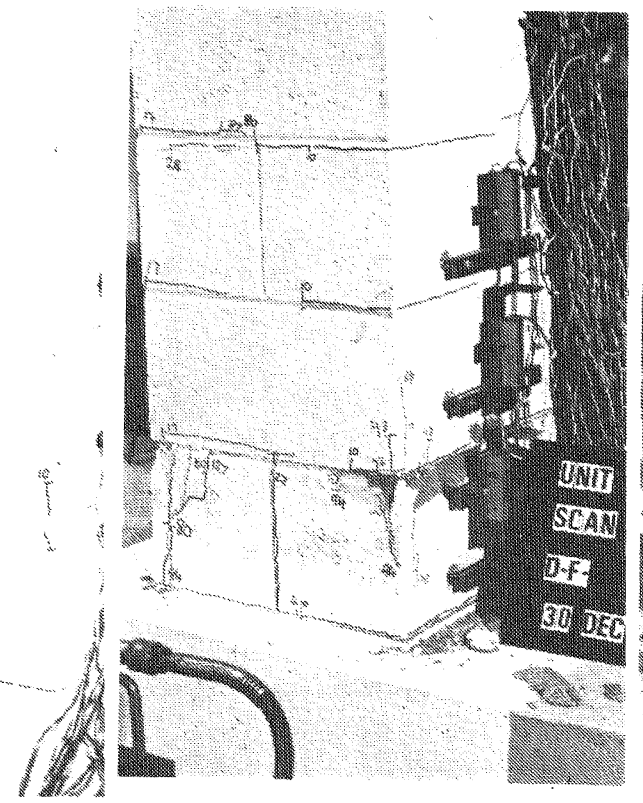

(b)

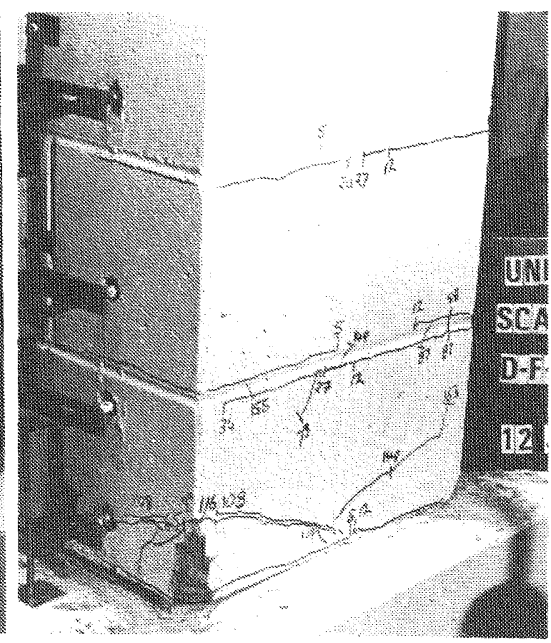

(e)

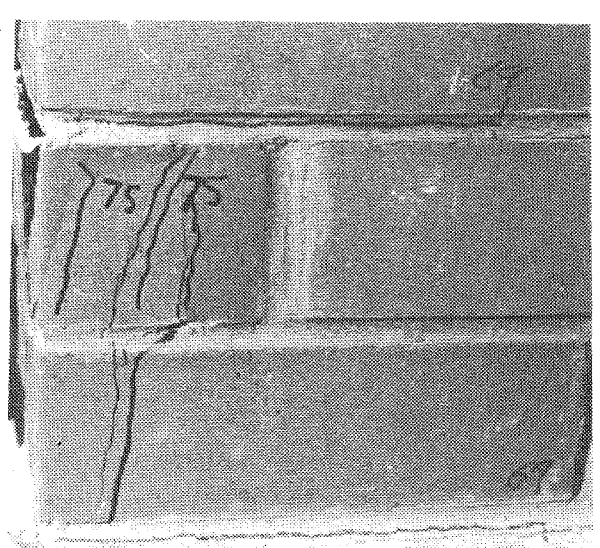

(h)

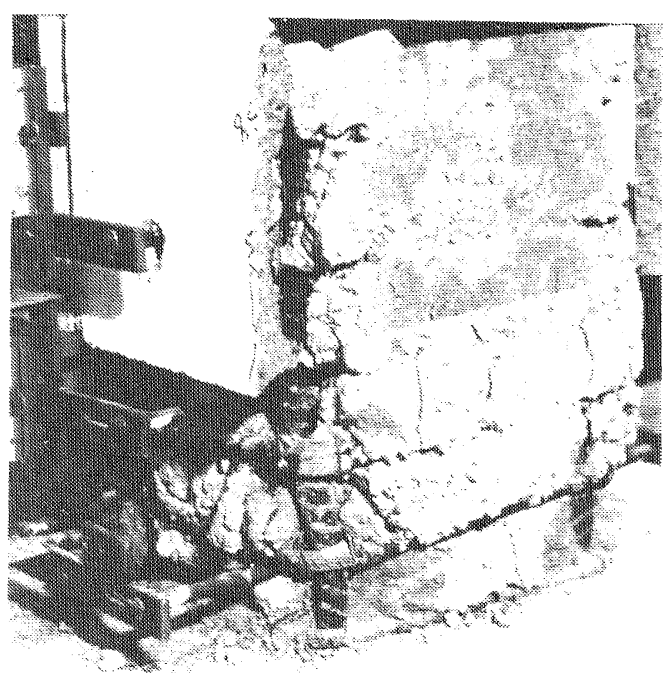

(c)

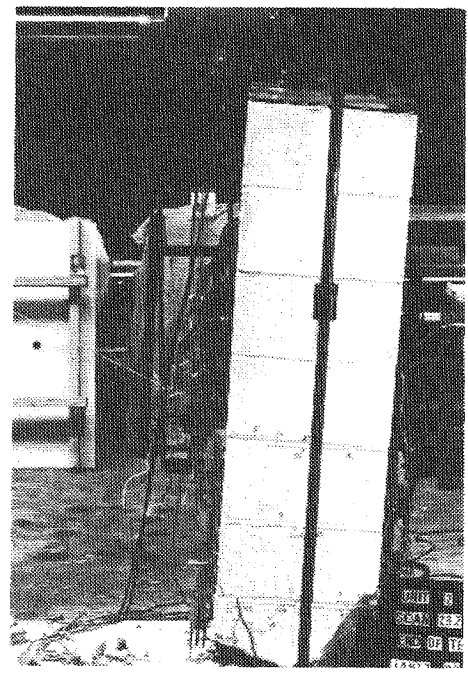

(f)

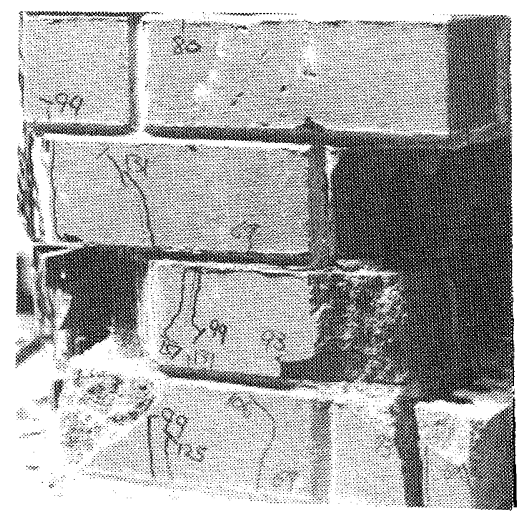

(i)

Figure 7. Condition of specimen during the tests. Specimen 1, (a) $\mu_{\Delta}=0.75$, (b) $\mu_{\Delta}=4$ and (c) end of test: Specimen 2, (d) $\mu_{\underline{\Delta}}=0.75,(e) \mu_{\underline{\Delta}}=6$ and $(f)$ end of test: Specimen 3, $(\mathrm{g})$ $\mu_{\underline{\Delta}}=0.75$, (h) $\mu_{\underline{\underline{\Delta}}}=2$ and (i) end of test. 


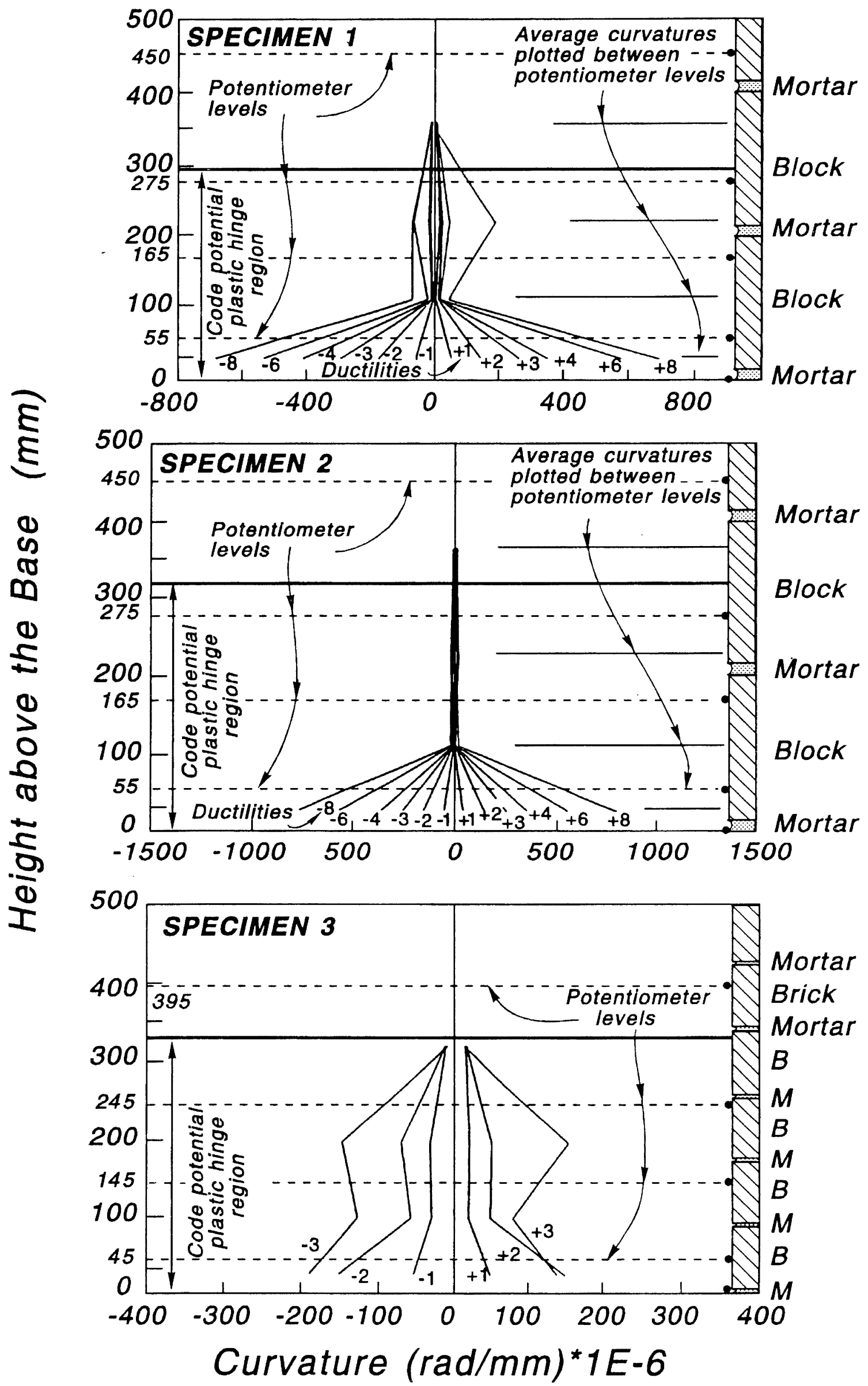

Figure 8. Measured average curvatures versus depth of columns for (a) Specimen 1, (b) Specimen 2 and (c) Specimen 3. 


\section{TEST OBSERVATIONS}

\section{(a) Splitting and Cracking}

Figure 7 shows a sequence of photographs taken during testing of the three column specimens. Horizontal cracks along the mortar joints within the plastic hinge zone on the tension side of the columns are visible in the photographs at a displacement ductility factor of $\mu_{\Delta}=0.75$. Fine base cracks also appeared at this stage.

Vertical splitting in the bottom courses was generated on the compression side of the columns before the maximum load was reached. This is a typical behaviour of masonry members when the mortar joints are not confined, for example by galvanised or stainless steel plates. At the maximum load, extensive crushing of the clay brick and concrete face shells occurred and the face shells eventually spalled off with a resulting decrease in lateral load.

\section{(b) Curvatures}

During the tests it was observed that the curvatures in the mortar joints were proportionately larger than the curvatures measured over the masonry blocks. This was particularly true for the curvatures at the lowest level adjacent to the base, which were very large because the gauge lengths included a wide crack in the base mortar joint (see Figure 8 ). This was already very noticeable when the displacement at the top of the columns was equal to the yield displacement. Consequently, the yield curvature could not be calculated accurately from the average curvature at the lowest level. Figure 9 shows a plot of all the measured curvatures at each of the five levels. These were linearly extrapolated for both loading directions separately as follows

$$
\Phi_{y}=\frac{1}{5} \sum_{i=1}^{5} \Phi_{i} \frac{1400}{x_{i}} \ldots \ldots \ldots \ldots \ldots \ldots
$$

These were then averaged to define the average yield curvature, $\Phi_{y}$, corresponding to the yield displacement $\Delta_{y}$. These values are shown in Table 3.

The experimental ultimate curvatures, $\Phi_{u}$, were taken as the curvatures when the measured flexural strength of the columns had reduced to approximately $80 \%$ of the theoretical ideal strength. Unfortunately, for Specimens 1 and 2 the potentiometers went out of range above ductility factor 8 , at which the load carrying capacity of the columns was still greater than the $80 \%$ of the theoretical ultimate load. At a ductility factor of 8 , curvature ductility factors, $\Phi_{\mathrm{u}} / \Phi_{\mathrm{y}}$, of approximately 13 and 16.5 were achieved for Specimens 1 and 2 respectively.

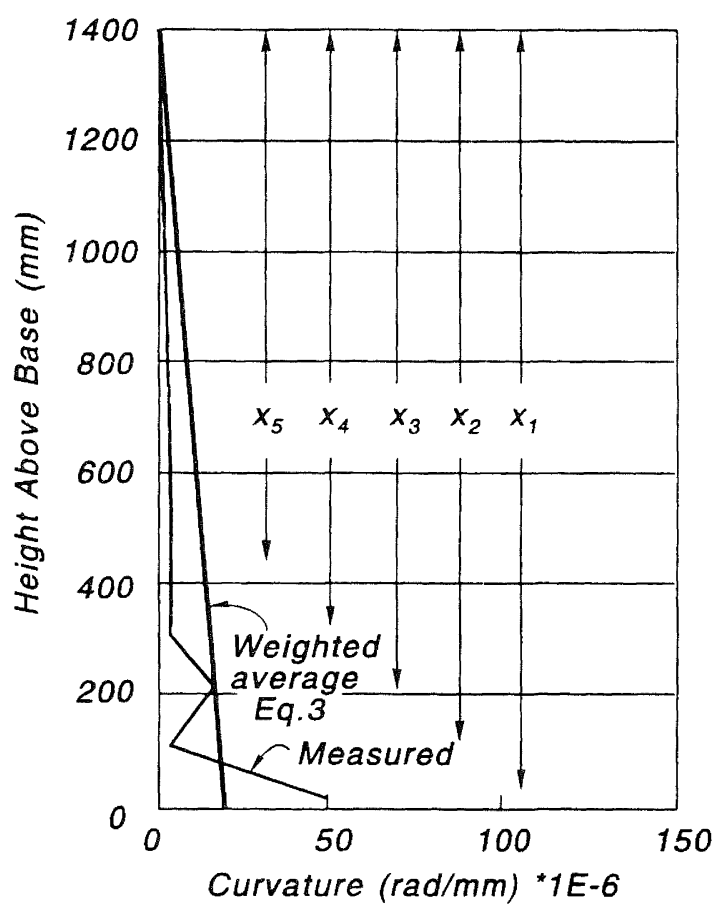

Figure 9. Measured and weighted average curvatures at the yield load.

Specimen 3 reached a curvature ductility factor of approximately 7.7 at a ductility factor of 3 .

The lateral load is plotted in Figure 10 against the average curvature measured by the potentiometers close to the base block for all three specimens. They show degradation of stiffness with increasing curvature levels for all three piers. Some pinching is evident, but the major difference between the concrete piers and the brick pier is that the loops are very open for the concrete piers and narrow for the brick pier indicating respectively a more ductile and less ductile type of behaviour.

\section{(c) Load-Displacement Characteristics}

The measured lateral load-displacement hysteresis loops of Specimen 1 are depicted in Figure 11. It can be seen that the hysteresis loops show very good energy-dissipating characteristics and stability. With increasing displacement ductility, some stiffness degradation is apparent.

Table 3 Experimental Values for Spécimens 1, 2 and 3

\begin{tabular}{|c|c|c|c|c|c|c|c|}
\hline $\begin{array}{c}\text { Specimen } \\
\#\end{array}$ & $\begin{array}{c}\Delta_{\mathrm{y}} \\
(\mathrm{mm})\end{array}$ & $\begin{array}{c}\Phi_{\mathrm{y}} \\
(\mathrm{rad} / \mathrm{mm})\end{array}$ & $\begin{array}{c}\Delta_{\mathrm{u}} \\
(\mathrm{mm})\end{array}$ & $\Delta_{\mathrm{u}} / \Delta_{\mathrm{y}}$ & $\Phi_{\mathrm{u}} / \Phi_{\mathrm{y}}$ & $\Delta_{\mathrm{u}} / \ell \times 100$ & $\begin{array}{c}\mathrm{H}_{\max } \\
(\mathrm{kN})\end{array}$ \\
\hline 1 & 8.90 & $17.0 \times 10^{-6}$ & 89.0 & 10 & 13 & $6.3 \%$ & 72.0 \\
\hline 2 & 8.0 & $15.9 \times 10^{-6}$ & 80.0 & 10 & 16.5 & $5.7 \%$ & 81.0 \\
\hline 3 & 11.30 & $19.0 \times 10^{-6}$ & 34.0 & 3 & 7.7 & $2.4 \%$ & 42.5 \\
\hline
\end{tabular}


(a)

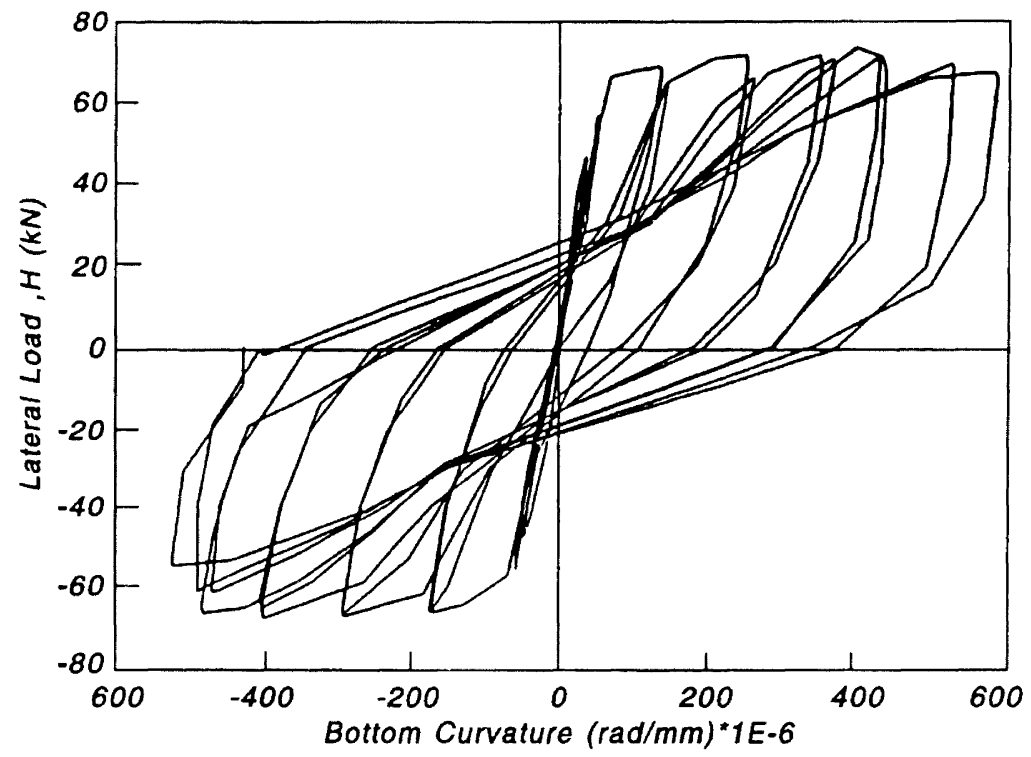

(b)
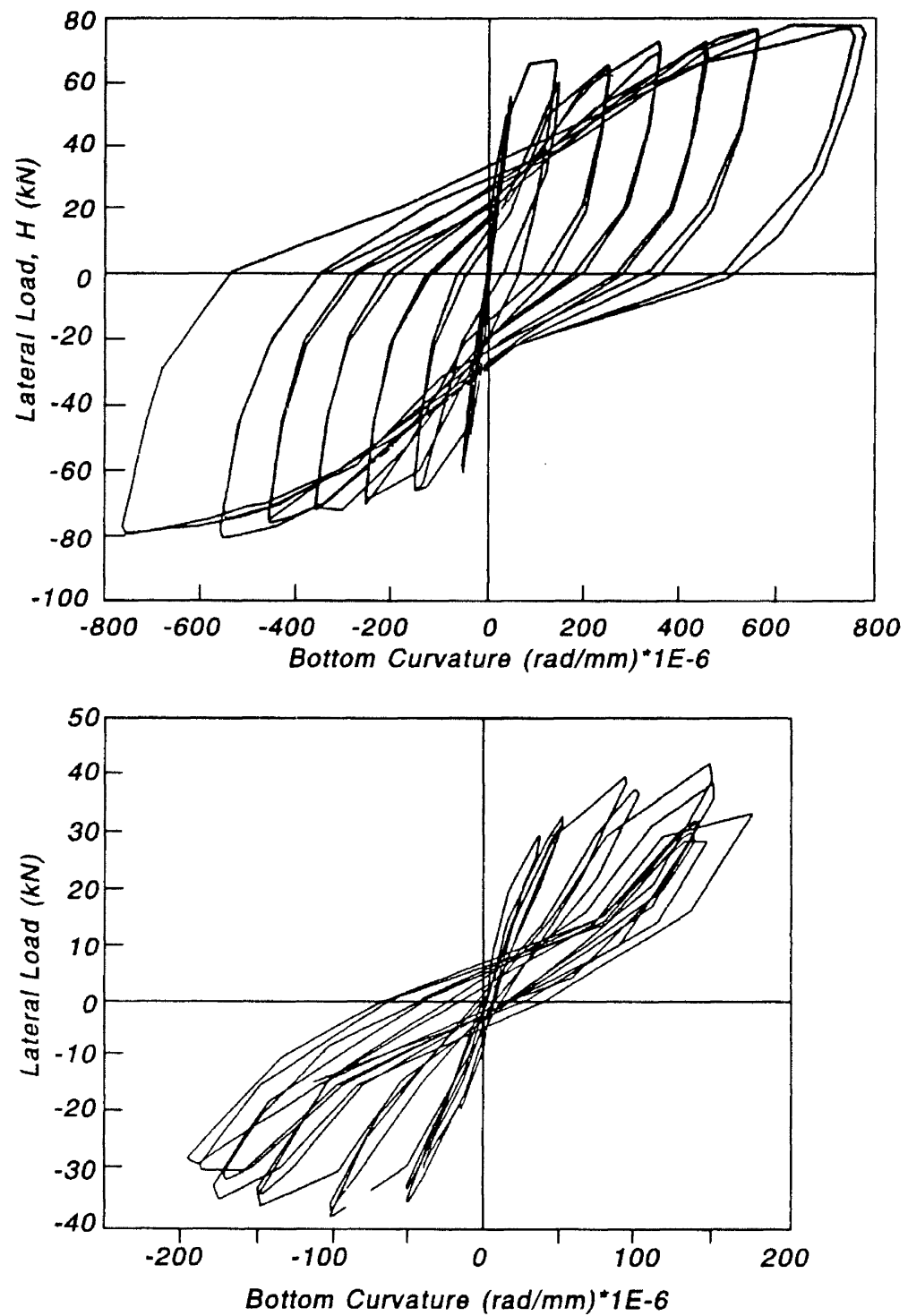

Figure 10. Experimental lateral load versus bottom curvature hysteresis loops for (a) Specimen 1, (b) Specimen 2 and (c) Specimen 3. 


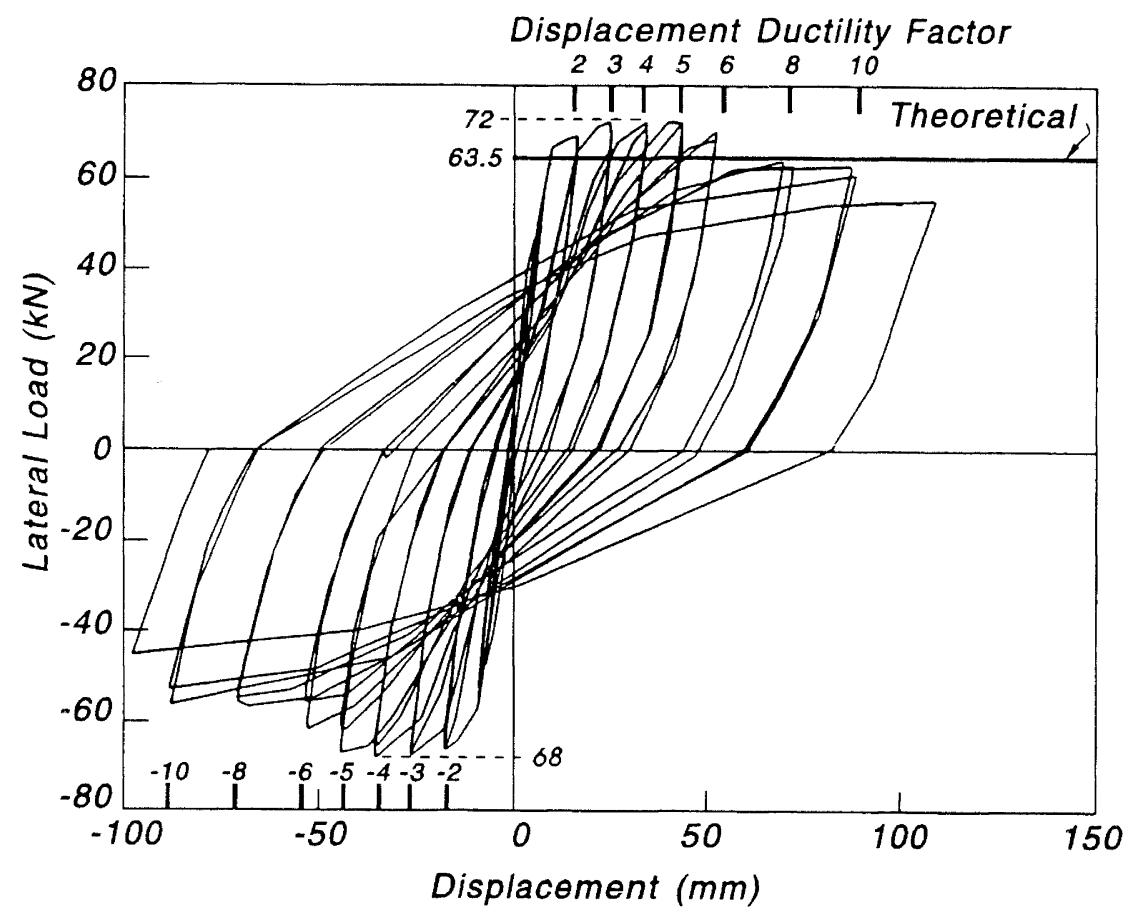

Figure 11. Experimental lateral load-displacement hysteresis loops for Specimen 1.

The maximum load-carrying capacity of the column was $72.0 \mathrm{kN}$ and $-67.5 \mathrm{kN}$ at a displacement ductility of $\mu_{\Delta}= \pm 3$. The average of these two load values was $15 \%$ greater than the theoretical value based on the full cross-section and $35 \%$ greater than the capacity based on the core concrete only. The dramatic reduction in strength between ductilities \pm 5 and \pm 8 is a result of the face shells spalling, leaving the core concrete to carry the load. At a displacement ductility of 10 , the maximum experimental load is approximately equal to the theoretical ideal ultimate capacity, and $83 \%$ of the maximum experimental load. When the column was loaded to $\mu_{\Delta}=+12.40$ and $\mu_{\Delta}=-11$ after completing two cycles of $\mu_{\Delta}= \pm 10$, the longitudinal bars in the compression region buckled, causing a significant reduction in lateral load-resisting capacity and a sudden failure.

The measured lateral load displacement hysteresis loops of Specimen 2 are depicted in Figure 12. It can be seen that the hysteresis loops are even more satisfactory than those for Specimen 1. With increasing displacement ductility, some stiffness degradation is again apparent. The face shells were well restrained by the central walls of the masonry unit and no degradation of strength occurred until the second cycle at ductility factor $\mu_{\Delta}=+10$. The strength degradation during the first cycle was only $5 \%$, indicating a level of toughness which is very satisfactory. When the column was loaded to $\mu_{\Delta}=+11.12$ after completing two cycles of $\mu_{\Delta}= \pm 10$, the longitudinal bars in the compressive region buckled, causing a sudden failure.

The measured lateral load-displacement hysteresis loops of Specimen 3 are depicted in Figure 13. It can be seen that the performance of Specimen 3 was less satisfactory than the others. The theoretical ultimate load was exceeded by $9 \%$ when the maximum load of $42.5 \mathrm{kN}$ was reached at a ductility of 2 . At a displacement ductility factor of $\mu_{\Delta}= \pm 3$, the experimental flexural strength had decreased to $85 \%$ of the theoretical ideal flexural strength of the column. However, the maximum experimental flexural strength measured in the opposite direction of loading only reached $98 \%$ of the theoretical maximum load at a displacement ductility of 1.5 . This decreased to $78 \%$ of theoretical at a displacement ductility of 3 .

\section{(d) Flexural overstrength}

The flexural overstrength factors $\mathrm{M}_{\max } / \mathrm{M}_{\mathrm{i}}$ were 1.14 and 1.18 for Specimen 1 and 2 respectively where $M_{\max }$ is the maximum measured moment capacity and $\mathbf{M}_{\mathrm{i}}$ is the theoretical flexural strength based on the measured yield strength of the steel reinforcement, neglecting strain hardening, the measured concrete compressive strength neglecting the effect of confinement, and maximum compressive strain of 0.003 for Specimens 1 and 2 and 0.0025 for Specimen 3.

The flexural strength enhancement equation given by Ang [1985] was found to be 1.22 for Specimens 1 and 2. This agrees reasonably well with the actual flexural overstrength factor for Specimen 2 but not for Specimen 1.

\section{(e) Spalling strains}

The masonry compressive strain, $\epsilon_{\text {spall }}$, when spalling of the face shell commenced, was estimated as $0.0065,0.0085$ and 0.0028 for Specimens 1, 2 and 3, respectively.

\section{(f) Equivalent plastic hinge length}

The equivalent plastic hinge length, $\ell_{\mathrm{p}}$, may be found from the plastic displacement, $\Delta_{p}$, by taking the first moment of area of an idealised rectangular distribution of the plastic curvature about the point of contraflexure of the column, leading to the following relationship: 


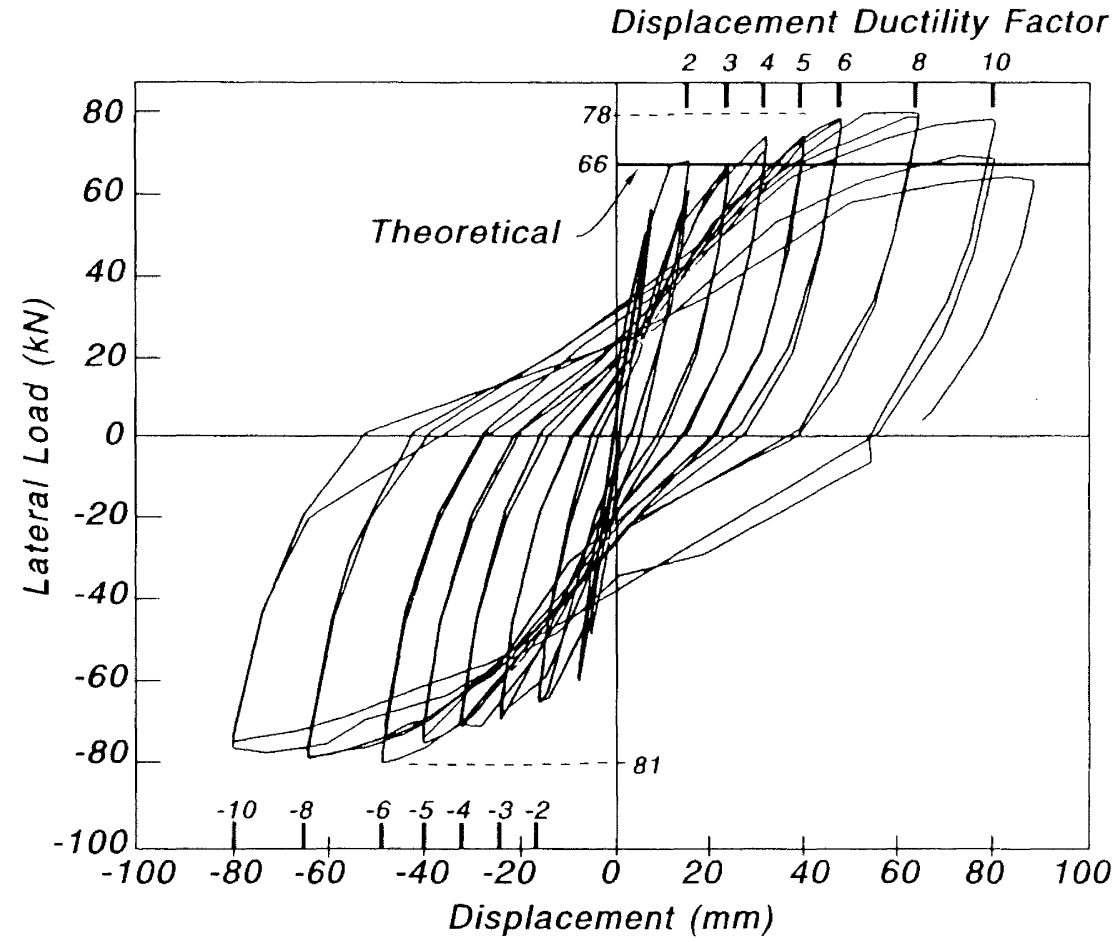

Figure 12 Experimental lateral load-displacement hysteresis loops for Specimen 2

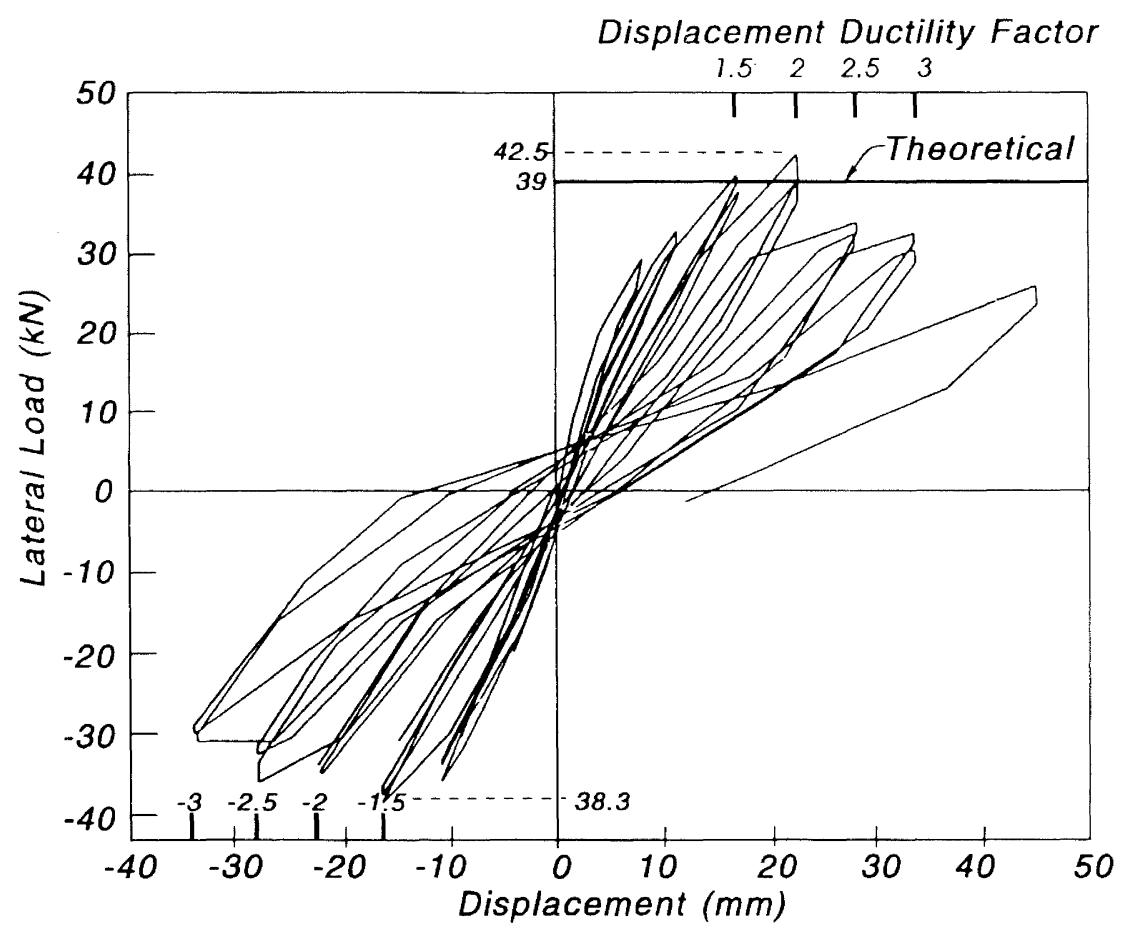

Figure 13. Experimental lateral load-displacement hysteresis loops for Specimen 3. 


$$
\frac{\ell_{p}}{h}=\frac{\ell}{h}\left(1-\sqrt{1-\frac{2\left(\mu_{\Delta}-1\right) \Delta_{y}}{\ell^{2}\left(\Phi_{u}-\Phi_{y}\right)}}\right) \ldots \ldots
$$

The values from this expression for Specimens 1, 2 and 3 are $0.72,0.52$ and 0.36 respectively.

According to Priestley and Park [1984], the predicted equivalent plastic hinge length can be found approximately from the expression:

$$
\ell_{\mathrm{p}}=0.08 \ell+6 \mathrm{~d}_{\mathrm{b}}
$$

This equation gives $\ell_{\mathrm{p}} / \mathrm{h}$ values of $0.62,0.62$ and 0.66 for Specimens 1, 2 and 3, respectively.

Figure 8 shows the distribution of measured average curvature near the base of each pier. It is clear from the measurements of Specimen 2 that all the plastic curvature occurred in the bottom mortar joint. Specimen 1 shows a similar trend, but with some additional plastic curvature in the adjacent mortar joint. It is therefore probably inappropriate to use Equations 4 and 5 which were derived from reinforced concrete specimens, for masonry specimens. The mortar joints of the brick pier are at a closer spacing with the result that the curvature distribution is more uniform and resembles the distribution in a reinforced concrete pier.

\section{CONCLUSIONS}

The conclusions reached during this study may be summarized as follows

1. Specimen 1 constructed with concrete masonry 20.36 units performed extremely well. A ductile failure was observed at the end of testing and a displacement ductility factor of 10 during cyclic loading was achieved, indicating that the transverse hoops provided adequate confinement to the concrete core, prevented premature buckling of the longitudinal bars, and provided sufficient shear resistance.

2. Specimen 2 , made from concrete masonry 20.30 units, also performed extremely well and reached a displacement ductility factor of 10 during cyclic loading. The test indicated that the transverse hoops effectively confined the concrete core even though the spacing of the hoops was $0.25 \mathrm{~h}$, greater than the limit of $0.20 \mathrm{~h}$ required by the Code, NZS3101.

3. The design of the concrete masonry columns was based on the assumption that the masonry face could be ignored in the analysis for strength and ductility, i.e. the design was based entirely on the concrete core alone. However, it was observed during the testing that the experimental strengths and ductilities were greater than the theoretical strengths and ductilities based on the full column sections. Face shells did not spall until a ductility of 5 for Specimen 1 and 10 for Specimen 2. The full column sections can be used in design.

4. It was observed during testing that the minimum spalling strain of the masonry face for concrete masonry columns was 0.0065 . Therefore, the use of the extreme fibre masonry compressive strain of 0.0025 in calculations is inevitably conservative and a value of 0.003 could be used in the design calculations. Spalling of the clay masonry column was observed at an extreme fibre strain of the brick face of 0.0028 . Therefore, the use of the extreme fibre masonry compressive strain of 0.0025 is a reasonably good representation.

5. The column tested with centre-to-centre spacing of the hoop sets of up to $0.25 \mathrm{~h}$ led to satisfactory performance. It is proposed that the Code NZS3101 limitations for centre-tocentre spacing of the hoop sets should be $1 / 4$ of the least lateral dimension of the cross-section instead of $1 / 5$.

6. It was observed during testing that a very good performance was shown by the concrete masonry columns in which the core concrete and reinforcement both comply with the reinforced concrete Code NZS3101. Ductility factors of 10 were achieved without significant strength degradation. It follows therefore, that these column types can be designed as ductile members.

7. It was observed during testing that the clay brick column did not behave in a sufficiently ductile manner and should therefore be designed as a member capable of sustaining only limited ductility.

8. Enhanced strengths resulting from confinement of the core concrete agreed well with the predictions made from Ang's [1985] equation for reinforced concrete columns.

\section{ACKNOWLEDGEMENTS}

The authors wish to acknowledge the financial and technical support provided by the Department of Civil Engineering, University of Canterbury. Especial thanks are due to Mr P. Murphy for his technical support and expertise.

\section{REFERENCES}

Ang, B.G., Priestley, M.J.N. and Paulay, T. 1985. Seismic Shear Strength of Circular Bridge Piers. Research Report 85-5, Department of Civil Engineering, University of Canterbury, Christchurch, $408 \mathrm{p}$.

Paulay, T. and Priestley, M.J.N. 1992. Seismic Design of Reinforced Concrete and Masonry Buildings. John Wiley and Sons.

Priestley, M.J.N. and Park, R. 1984. Strength and Ductility of Bridge Substructures. Bulletin No. 71, Road Research Unit, NZ National Roads Board, Wellington, 113 p.

Singh, H. 1993. Ductile Behaviour of Reinforced Concrete Masonry Columns. Master of Engineering Report, Department of Civil Engineering, University of Canterbury, Christchurch, 117 p.

Standards Association of New Zealand. 1980. Code of Practice for the Design of Concrete Structures, NZS3101. Wellington, New Zealand.

Standards Association of New Zealand. 1990. Code of Practice for the Design of Masonry Structures, NZS4230. Wellington, New Zealand. 
NOTATION

$\mathrm{d}_{\mathrm{b}} \quad=$ longitudinal bar diameter

$f_{\mathrm{cb}}^{\prime} \quad=$ uniaxial compression strength of masonry unit

$\mathrm{f}_{\mathrm{g}}^{\prime} \quad=$ compression strength of grout

$\mathrm{f}_{\mathrm{m}}^{\prime} \quad=$ masonry compression strength

$\mathrm{f}_{\mathrm{p}}^{\prime}=$ longitudinal stress in mortar joint, sufficient to cause failure

$\mathrm{h}=$ overall depth of column section

$\mathrm{H}_{\max }=$ maximum lateral load occurred during testing

$\ell=$ distance from section of maximum moment to point of contraflexure

$\ell_{\mathrm{p}} \quad=\quad$ equivalent plastic hinge length

$\mathrm{M}_{\mathrm{i}} \quad=$ ideal flexural column strength

$\mathrm{M}_{\max }=$ experimental maximum flexure strength of column

$\mathrm{x}=$ ratio of shell area to gross area of a masonry unit

$\mathrm{x}_{\mathrm{i}}=$ distance from top of column to level $\mathrm{i}$

$\Delta_{u} \quad=$ maximum lateral displacement occurring during testing

$\Delta_{\mathrm{p}} \quad=$ plastic displacement

$\Delta_{\mathrm{y}} \quad=$ yield displacement

$\epsilon_{\text {spall }}=$ spalling strain of masonry

$\mu_{\Delta} \quad=$ displacement ductility factor

$\Phi_{\mathrm{i}} \quad=$ experimental curvature at level $\mathrm{i}$

$\Phi_{\mathrm{u}} \quad=$ ultimate curvature

$\Phi_{\mathrm{y}} \quad=$ yield curvature 